\title{
Tensile ductility improvement of AISi9Cu1 alloy by chemical composition optimization
}

\author{
${ }^{*}$ Bing-rong Zhang ${ }^{1,4}$, Jian-xiang Liu ${ }^{4}$, Shou-yin Zhang ${ }^{2}$, Song-li Zhang ${ }^{3}$ and Xin-ping Hu ${ }^{1}$ \\ 1. School of Mechanical and Automotive Engineering, Qilu University of Technology, Jinan 250353, China \\ 2. Light Alloy Processing Science and Defense Technology Key Laboratory, Nanchang Hangkong University, Nanchang 330063, China \\ 3. School of Materials Science and Engineering, Jiangsu University, Zhenjiang 212013, Jiangsu, China \\ 4. Shandong Tailai Aluminum Foundry Tech. Co. Ltd., Laiwu 270100, Shandong, China
}

\begin{abstract}
Diesel engines, characterized by higher breakout pressure and compression ratio in comparison with gasoline engines, require particularly elevated tensile properties for their engine parts. In order to maintain both high strength and high ductility in the cylinder head, i.e., to obtain higher percent elongation without further reducing the tensile strength, AlSi9Cu1 alloy was used to prepare the cylinder head in an aluminum diesel engine. At the same time, the effect of different modification elements, $\mathrm{Na}$ or $\mathrm{Sr}$, and $\mathrm{Fe}$ content on the reduction of secondary dendrite arm spacing (SDAS) was discussed, and the design of T7 heat treatment parameters were analyzed in order to improve the tensile ductility. The result shows: (1) The SDAS is as small as $18 \pm 3 \mu \mathrm{m}$ for the $\mathrm{Sr}$ modified alloy. (2) The percent elongation of the alloy with $\mathrm{Sr}$ modification increases by $66.7 \%$ and $42.9 \%$, respectively, compared with the unmodified alloy and the alloy with Na modification. (3) Lower Fe content alloy $(0.10 \%)$ gives good results in percent elongation compared to the alloy with higher Fe content $(0.27 \%)$; in particular, after $\mathrm{Sr}$ modification and $\mathrm{T7}$ heat treatment, the elongation of over $5 \%$ is obtained.
\end{abstract}

Key words: diesel engine cylinder head; high temperature tensile properties; aluminum alloys; modification; combination of strength and ductility

CLC numbers: TG146.21 Document code: A Article ID: 1672-6421(2017)02-080-05

$\mathrm{D}$ esel engines are used more and more widely in North America and Europe for passenger cars and light trucks because of their high fuel efficiency and reduced greenhouse gas emissions. These diesel engine components require a higher tensile property due to higher compression ratio and maximum breakout pressure of diesel engine compared with gasoline engines. Despite many advantages in the development of aluminum alloys, the alloys currently used for gasoline engine parts, typically A356 and 319 alloys, cannot meet the demand for high heat resistance ${ }^{[1-5]}$.

In our previous work ${ }^{[6]}$, we studied the influence of the secondary dendrite arm spacing (SDAS) as well as the combination of the SDAS and the heat treatment parameters on the mechanical properties of a cylinder head of A356 alloy. We found that the A356 alloy cylinder head with smaller SDAS reached its peak value

\footnotetext{
* Bing-rong Zhang

Male, born in 1958, Professor and Ph.D. Research interest: Nonferrous alloy applications in automotive and aviation.

E-mail: brzit@aliyun.com
}

Received: 2016-07-10; Accepted: 2016-12-19 of hardness (HB), ultimate tensile strength (UTS) and yield strength (YS) at a lower aging temperature, but the over-aged structure was also yielded earlier. One of the most important factors that limit the use of A356 alloy for diesel cylinder head is its lower tensile properties at elevated temperatures: the properties of A356 (without $\mathrm{Cu})$ alloy deteriorate seriously when temperature reaches $250{ }^{\circ} \mathrm{C}^{[1-5]}$. The diesel cylinder head being developed requires an optimum combination of strength and elongation: UTS $\geqslant 290 \mathrm{MPa}, \mathrm{YS} \geqslant 240 \mathrm{MPa}$, percent elongation $\geqslant 4.5 \%$ and $\mathrm{HB}$ from 95 to 125 , and for gravity casting, a value of SDAS not higher than 25 micron in the combustion chamber. To meet these requirements, we selected a candidate alloy containing copper - AlSi9Cu1 to produce the diesel cylinder head.

The chemical compositions of the commercial AlSi9Cu1 are very similar to alloy 354 of the AFS (the American Foundrymen's Society). It is an alloy used by the Cummins Company for diesel engine cylinder heads. The increased silicon content contributes to its excellent castability. Its excellent fluidity and resistance to hot cracking make it possible to produce castings larger in size and more intricate in design. Its copper content, from $0.8 \%$ to $1.3 \%$ in standard, allows it to have a 
higher hardness than A356 alloy. At the same time, compared with another commonly used alloy in automotive - 319 alloy, because of its lower iron and copper content, AlSi9Cu1 alloy can have greatly improved tensile and elongation properties. The problem we met in the test on cylinder head castings was that the elongation was only about $2.5 \%$ while its strength reached about $300 \mathrm{MPa}$ using commercial alloys of AlSi9Cu1. So, the experiment focuses on how to improve the elongation without further reducing the tensile strength, through the optimization of its chemical compositions.

In the AlSi9Cu1 cast alloy, the size and morphology of the eutectic Si have a significant influence on the mechanical properties. Therefore, various modification elements were used to change the acicular eutectic Si into a fibrous structure $^{[7-11]}$. $\mathrm{Na}$ and $\mathrm{Sr}$ are usually applied and show good modification effect ${ }^{[7]}$. Besides, the Fe exists in the alloy as a long, thick needles/platelets $\beta-\mathrm{Al}_{5} \mathrm{FeSi}$ intermetallic phase, which results in low mechanical properties, in particular, a low percent elongation. The tensile ductility of AlSi9Cul alloy is not only related to the modification elements and Fe content, but also to heat treatment, because for some intermetallic phases, such as $\mathrm{Al}_{2} \mathrm{Cu}$, the way to improve the strength is through the precipitation-hardening heat treatment.

Thus, the study on the tensile ductility improvement is focused on the following three aspects: the selection of modification elements, $\mathrm{Sr}$ or $\mathrm{Na}$; the reduction of Fe content, and the design of heat treatment parameters.

\section{Experimental procedure}

Figure 1 shows the cylinder head casting for a diesel engine. The nominal chemical compositions of AlSi9Cul are listed in Table 1. Commercial AlSi9Cul alloy was melted at $750{ }^{\circ} \mathrm{C}$ in a graphite crucible using an electric induction furnace. $50 \mathrm{ppm}$ (of the mass of AlSi9Cu1) $\mathrm{Na}$ or $90 \mathrm{ppm} \mathrm{Sr}$ modifiers were added in $\mathrm{NaF}$ compound or $\mathrm{Al}-\mathrm{Sr}$ intermediate alloy into the molten metal at $720 \pm 5^{\circ} \mathrm{C}$. Then, the molten metal was stirred and degassed using dry pure nitrogen for 15 min with a graphite rotation degassing machine. The pouring temperature was $720 \pm 5^{\circ} \mathrm{C}$.

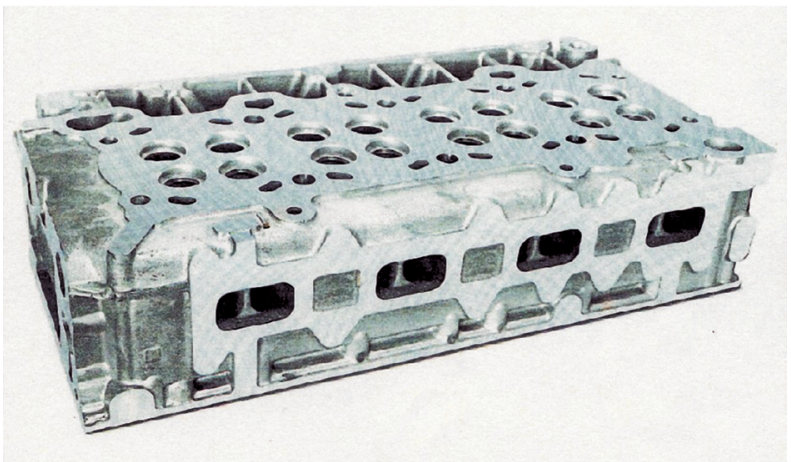

Fig. 1: Cylinder head for a diesel engine

Table 1: Nominal chemical compositions of AISi9Cu1 (wt.\%)

$\begin{array}{ccccc}\mathrm{Si} & \mathrm{Cu} & \mathrm{Mg} & \mathrm{Fe} & \mathrm{Ti} \\ 9.0-10.0 & 0.80-1.30 & 0.25-0.50 & \leqslant 0.30 & \leqslant 0.10\end{array}$

All pouring tests of cylinder heads were performed on mass production equipment - FATA Gravity Casting Line and with the same SPM (Semi-Permanent-mold) tooling. The solidification time of all the cylinder heads was $270 \mathrm{~s}$. To study the effect of Fe element on mechanical properties, two batches of commercial AlSi9Cu1 alloys were used to cast samples under the same conditions, one batch containing $0.27 \% \mathrm{Fe}$, and the other containing $0.10 \% \mathrm{Fe}$.

Heat treatment cycles were designed considering the overaging of the castings, through high aging temperature (T7) or through prolonged time (T6).

Table 2: Heat treatment parameters

\begin{tabular}{|c|c|c|c|c|c|}
\hline \multirow{2}{*}{$\begin{array}{c}\text { Heat } \\
\text { treatment }\end{array}$} & \multicolumn{2}{|c|}{ Solution } & \multirow{2}{*}{ Quenching } & \multicolumn{2}{|c|}{ Aging } \\
\hline & $T\left({ }^{\circ} \mathrm{C}\right)$ & $t(h)$ & & $T\left({ }^{\circ} \mathrm{C}\right)$ & $t$ (h) \\
\hline T6 & 515 & 6 & & 160 & 12 \\
\hline \multirow{2}{*}{ T7 } & 515 & 6 & $60^{\circ} \mathrm{C}$ & 225 & 6 \\
\hline & 515 & 6 & & 245 & 6 \\
\hline
\end{tabular}

The specimens for microstructure observation and tensile properties test were cut from the fire deck face of the cylinder heads, as shown in Fig. 2. Samples were machined in cylinder shape with a diameter of $10 \mathrm{~mm}$. The tensile test was performed using a computer controlled ZWICK machine. A minimum of two castings ( 6 test-bars for each casting) were used. SDAS measurement was done on the fracture surface of tensile test bars after normal metallographic techniques of mounting, polishing and etching ${ }^{[12]}$. The SDAS value is the average of at least 4 measurements.

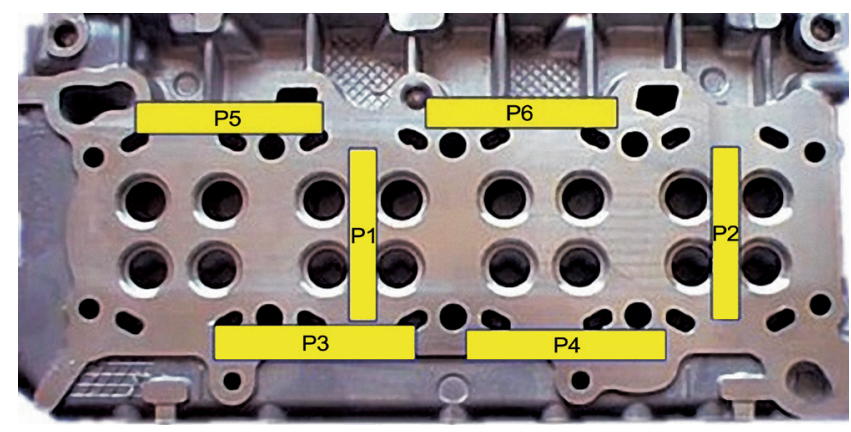

Fig. 2: Tensile test samples from fire deck face

\section{Results and discussion}

\subsection{SDAS and tensile properties of AISi9Cu1 alloy}

Finer dendrite arm spacing is beneficial to mechanical properties of aluminum alloy castings. The SDAS value should be not higher than $25 \mu \mathrm{m}$ in the combustion chamber according to the Engineering specifications for the cylinder head. The microstructure of the as-cast cylinder head produced from AlSi9Cu1 $(0.27 \% \mathrm{Fe})$ modified with $90 \mathrm{ppm} \mathrm{Sr}$ is shown in Fig. 3 , and the SDAS value is shown in Table 3. 


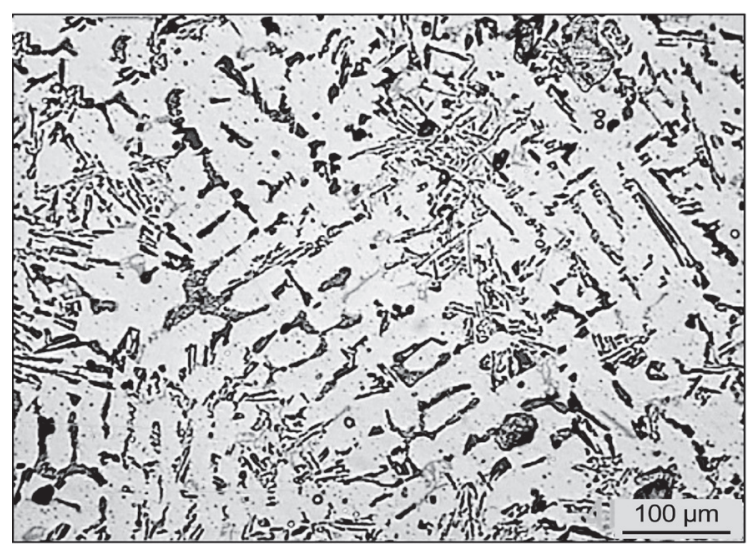

Fig. 3: Microstructure of AISi9Cu1 (0.27\% Fe) alloy modified with $\mathrm{Sr}$

Table 3: SDAS of AISi9Cu1 (0.27\% Fe) alloy modified with $\mathrm{Sr}$

\begin{tabular}{ccc} 
Sample number & SDAS $(\mu \mathrm{m})$ & Average $(\mu \mathrm{m})$ \\
1 & $17 \pm 1$ & \\
2 & $20 \pm 1$ & $18 \pm 3$ \\
3 & $18 \pm 2$ & \\
\hline
\end{tabular}

As shown in Fig. 3, the secondary dendrite arms are welldistributed with a uniform size. The average secondary dendrite arm spacing is $18 \pm 3 \mu \mathrm{m}$, far less than $25 \mu \mathrm{m}$. Such results are consistent with the composition versus dendrite cell size curves produced by Spear and co-workers ${ }^{[13]}$, which clearly showed the influence of four major alloying elements - $\mathrm{Si}, \mathrm{Cu}, \mathrm{Mg}, \mathrm{Zn}$ on dendrite. The dendrite cell size decreases with the increase of alloying elements. In this work, the high silicon content and the addition of Sr contribute together to lower the value of SDAS.

Figure 4 shows the ultimate tensile strength (UTS), yield strength (YS), hardness (HB) and elongation (E\%) of the alloy modified with $\mathrm{Sr}$ after T6 and T7 heat treatments.

As shown in Figs. 4(a)-(c), UTS, YS and HB changed little when the aging parameters changed from $160^{\circ} \mathrm{C} \times 12 \mathrm{~h}$ to 225 ${ }^{\circ} \mathrm{C} \times 6 \mathrm{~h}$ for AlSi9Cu1 alloy modified with Sr. These properties obviously decreased when the aging temperature increased to $245^{\circ} \mathrm{C}$, with the UTS of $276 \mathrm{MPa}$, YS of $208 \mathrm{MPa}$ and $\mathrm{HB}$ of 88 , respectively. The elongation values in the three different aging cycles ranged from $3.6 \%$ to $4.8 \%$, much higher than the $2.5 \%$ of the as-cast A1Si9Cu1 alloy. Although we obtained a higher elongation as $4.8 \%$ with $\mathrm{T} 7\left(245^{\circ} \mathrm{C} \times 6 \mathrm{~h}\right)$ heat treatment, the UTS, YS and HB can not meet the technical requirements for the cylinder head casting for the diesel engine. Considering the casting specification requirement and the severe service conditions of cylinder head, the effect of modification elements, $\mathrm{Sr}$ or $\mathrm{Na}$ and the influence of $\mathrm{Fe}$ content on tensile properties of AlSi9Cul alloy with $\mathrm{T} 7\left(225^{\circ} \mathrm{C} \times 6 \mathrm{~h}\right)$ heat treatment were studied.

\subsection{Effect of $\mathrm{Na}$ or $\mathrm{Sr}$ modification on tensile properties of AISi9Cu1 alloy containing $0.27 \% \mathrm{Fe}$}

Figure 5 shows the tensile properties of the Sr-modified AlSi9Cu1 alloy after $\mathrm{T} 7\left(225^{\circ} \mathrm{C} \times 6 \mathrm{~h}\right)$ heat treatment. It can be seen that the UTS and YS are not strongly affected by $50 \mathrm{ppm}$ $\mathrm{Na}$ or $90 \mathrm{ppm} \mathrm{Sr}$ modification, but the modification in all the tests substantially improved the percent elongation of the alloy after the $\mathrm{T} 7$ heat treatment.
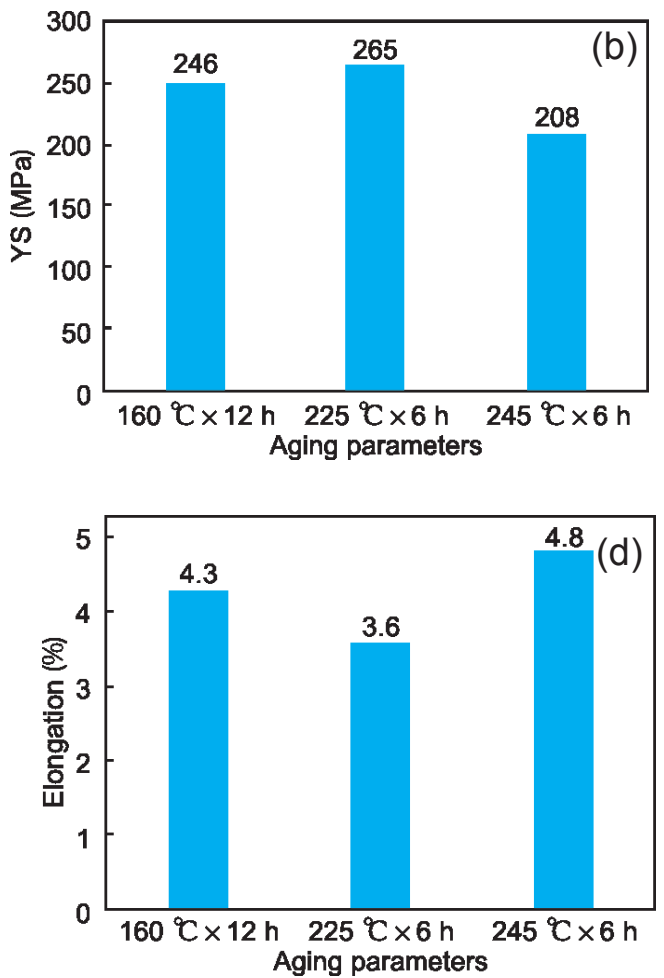

Fig. 4: Tensile properties of AISi9Cu1 $(0.27 \% \mathrm{Fe})$ alloy modified with Sr after T6 and T7 heat treatments: (a) UTS, (b) YS, (c) HB, (d) E\%

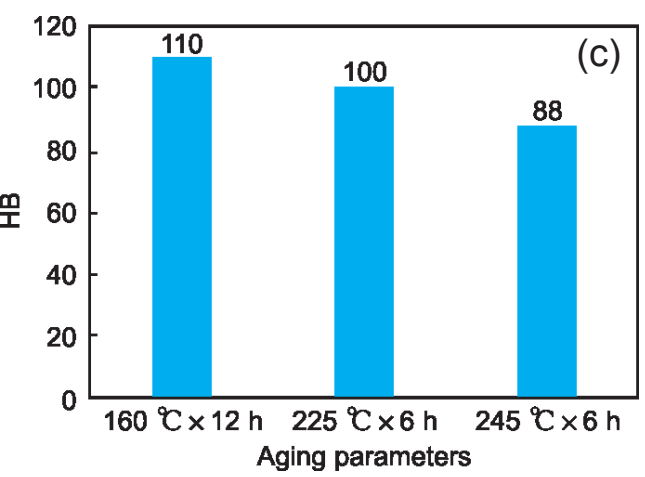



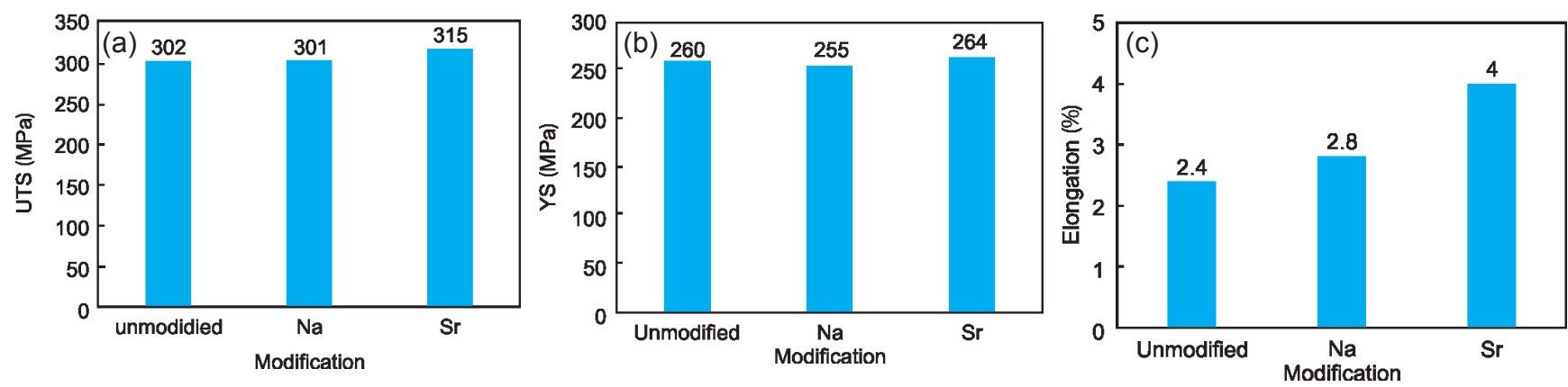

Fig. 5: Tensile properties of AISi9Cu1 (0.27\% Fe) alloy sample after T7 heat treatment $\left(225^{\circ} \mathrm{C} \times 6 \mathrm{~h}\right):$ (a) UTS, (b) YS, (c) E\%

Both $\mathrm{Na}$ and Sr modifications increased considerably the elongation of AlSi9Cul cylinder heads. The elongation of alloy modified with $\mathrm{Sr}$ was increased by $66.7 \%$ compared with that unmodified one, from $2.4 \%$ to $4 \%$, and by $42.9 \%$ compared with that of $\mathrm{Na}$ modification, from $2.8 \%$ to $4 \%$. Figure 6 shows the optical microstructures of the alloy with different modification elements.
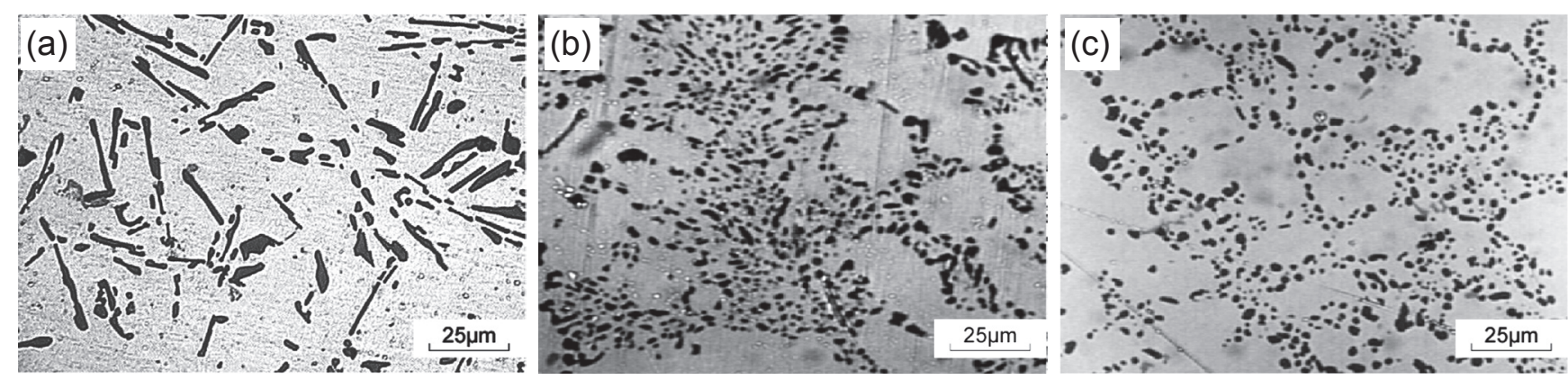

Fig. 6: Optical microstructures of AISi9Cu1 $(0.27 \% \mathrm{Fe})$ alloy after $\mathrm{T7}\left(225^{\circ} \mathrm{C} \times 6 \mathrm{~h}\right)$ heat treatment:

(a) unmodified, (b) modified with $50 \mathrm{ppm} \mathrm{Na}$ and (c) modified with $90 \mathrm{ppm} \mathrm{Sr}$

As shown in Fig. 6(a), without modification, the microstructure of the AlSi9Cu1 alloy mainly consists of acicular eutectic Si. In Fig. 6(b) - modified with 50 ppm Na and Fig. 6(c) - modified with $90 \mathrm{ppm} \mathrm{Sr}$, the Si phase changes from bars to mesh, and the distribution of $\mathrm{Si}$ in $\mathrm{Sr}$-modified alloy is more uniform than that modified with $\mathrm{Na}$. After being modified with $\mathrm{Sr}$, the needle, hard and brittle primary Si were broken into small fragments. The addition of $\mathrm{Sr}$ eliminates the inherent growth of the eutectic $\mathrm{Si}$, resulting in a large number of high density twinned crystals, showing the twin growth mechanism.

The secondary dendrite arm of the alloy modified with $\mathrm{Sr}$ is also smaller than that modified with $\mathrm{Na}$. It can be concluded that $90 \mathrm{ppm} \mathrm{Sr}$ has a better modification effect than $50 \mathrm{ppm} \mathrm{Na}$ for AlSi9Cu1 alloy. It was well known that the finer microstructure can improve the tensile properties, elongation in particular.
Figure 5 also indicates that the alloy tensile properties were greatly improved by the addition of $\mathrm{Sr}$.

\subsection{Effect of Fe content on tensile properties of AISi9Cu1 alloy}

Figure 7 shows the tensile properties of AlSi9Cul $(0.10 \% \mathrm{Fe})$ alloy after $\mathrm{T} 7$ heat treatment $\left(225{ }^{\circ} \mathrm{C} \times 6 \mathrm{~h}\right)$, confirming the results obtained on higher $\mathrm{Fe}(0.27 \%)$ alloy that $\mathrm{Sr}$ modification yields the best performances in percent elongation compared with $\mathrm{Na}$. In the low $\mathrm{Fe}(0.10 \%)$ AlSi9Cul alloy modified with $\mathrm{Sr}$, the elongation after $\mathrm{T} 7$ heat treatment increases to more than $5 \%$, and the alloy still maintains high ultimate tensile strength (>290 MPa) and yield strength (>240 MPa) values. The elongation is much higher than that of the alloy containing $0.27 \%$ Fe modified by $\mathrm{Na}$ or $\mathrm{Sr}$ after $\mathrm{T} 7$ heat treatment (Fig. 5c).
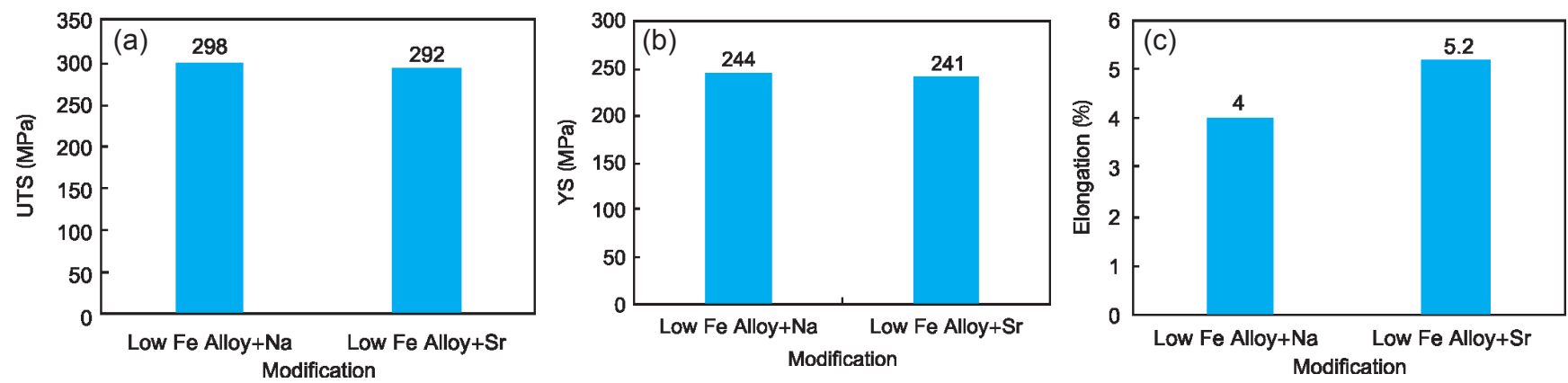

Fig. 7: Tensile properties of AISi9Cu1 alloy (0.10\% Fe) after T7 heat treatment $\left(225^{\circ} \mathrm{C} \times 6 \mathrm{~h}\right)$ : (a) UTS, (b) YS, (c) E\% 
A study on the role of trace elements in 319 alloy showed that increasing the iron content resulted in the precipitation of long, thick needles/platelets of the $\beta-\mathrm{Al}_{5} \mathrm{FeSi}$ intermetallic phase ${ }^{[14]}$. The increase of intermetallic needles/platelets would result in the decrease of percent elongation. Wu Xiaobo, et al ${ }^{[15]}$ studied the effect of Fe content from $0.12 \%$ to $1.91 \%$ as well as Fe phase morphology on the microstructure and mechanical properties of Al-Si Alloy. They found that with the increase of Fe content, tensile strength and elongation of castings were decreased, especially when the Fe content was from $0.12 \%$ to $0.97 \%$. The morphology of Fe phase was mainly dominated by bone or needle shapes in high $\mathrm{Fe}$ content alloy, which resulted in the decrease of elongation.

\section{Conclusions}

Based on the results of the experiments, the following conclusions can be obtained:

(1) The 90 ppm Sr modified AlSi9Cul (containing 0.27\% Fe) cylinder head has a low average SDAS as $18 \pm 3 \mu \mathrm{m}$. The ultimate tensile strength (UTS), yield strength (YS) and hardness of the alloy remain a high level after $\mathrm{T} 7\left(225^{\circ} \mathrm{C} \times 6 \mathrm{~h}\right)$ treatment, but obviously decrease when the aging temperature increases from $225{ }^{\circ} \mathrm{C}$ to $245{ }^{\circ} \mathrm{C}$, which can not meet the technical requirements for the cylinder head, although the elongation reaches a high level of $4.8 \%$. Therefore, $\mathrm{T} 7$ treatment $\left(225^{\circ} \mathrm{C} \times 6 \mathrm{~h}\right)$ is more applicable for the production of the AlSi9Cul cylinder head.

(2) Tensile test results show that $\mathrm{Sr}$ modification has no obvious influence on ultimate and yield strength properties, but it does improve the elongation values substantially for all tests. Sr addition results in higher elongation values than the Na modification. The elongation of the alloy with $\mathrm{Sr}$ modification increases by $66 \%$ compared with the unmodified alloy.

(3) AlSi9Cu1 alloy with a low Fe content $(0.10 \%)$ gives good results in elongation; in particular, with $\mathrm{Sr}$ modification and $\mathrm{T} 7$ heat treatment at $225^{\circ} \mathrm{C}$, a high elongation of $5.2 \%$ can be obtained, while still maintaining the high values of UTS (292 $\mathrm{MPa})$ and YS (241 MPa).

\section{References}

[1] Kasprzak W, Emadi D, Sahoo M, et al. Development of aluminum alloys for high temperature applications in diesel engines. Materials Science Forum, 2009, 618-619: 595-600.
[2] Garat M, Laslaz G. Improved aluminum alloys for common rail diesel cylinder heads. AFS Transactions, 2007: 209-215.

[3] Feliks F J. Optimization of Al-Si cast alloys for cylinder head applications.Transaction of the American Foundrymen's Society, 1998: 225-231.

[4] Onda H, Sakurai K, Masuta T, et al. The effect of solidification models on the prediction results of the temperature change of the aluminum cylinder head estimated by FDM solidification analysis. Materials Science Forum, 2007, 561-565: 1967-1970.

[5] Kitamura M, Liu W S, Tohriyama S, et al. Microstructure changes of partial re-melting reinforced A319 alloy for diesel cylinder head. ICAA-6: 6th International Conference on Aluminum Alloys, 1998: 309-314.

[6] Zhang Bingrong, Garro M, Giglio A, et al. Effect of dendrite arm spacing on mechanical properties of aluminum alloy cylinder heads and engine blocks. SAE Technical Paper Series, 2005 SAE World Congress, Detroit, Michigan, USA, 2005, 2005-011683: 11-14.

[7] Sang Soo S, Eok-Soo K, et al. Modification effect of Sr on the microstructures and mechanical properties of Al-10.5Si2.0 Cu recycled alloy for die casting. Materials Science and Engineering A, 2012, 532: 151-157.

[8] Choi H S, Li Xiaochun. Refinement of primary Si and modification of eutectic $\mathrm{Si}$ for enhanced ductility of hypereutectic Al-20Si-4.5Cu alloy with addition of $\mathrm{Al}_{2} \mathrm{O}_{3}$ nanoparticles. Journal of Materials Science, 2012, 47: 3096-3102.

[9] Samuel A M, Doty H W, Valtierra S. Effect of grain refining and Sr-modification interactions on the impact toughness of Al-SiMg cast alloys. Materials and Design, 2014, 56: 264-273.

[10] Elsebaie O, Samuel A M, Samuel F H. Effects of Srmodification, iron-based intermetallics and aging treatment on the impact toughness of $356 \mathrm{Al}-\mathrm{Si}-\mathrm{Mg}$ alloy. Journal of Materials Science, 2011, 46: 3027-3045.

[11] Zhang Yong, Zheng Hongliang, Liu Yue, et al. A novel Al-10Si$2 \mathrm{Fe}$ master alloy and its effect on inoculation of eutectic cells in Sr-modified A356 alloy. China Foundry, 2014, 02: 98-102.

[12] Zhang Bingrong, Garro M, Tagliano C. Dendrite arm spacing in aluminum alloy cylinder heads produced by gravity semipermanent mold. Metallurgical Science and Technology, 2003, 21: 3-9.

[13] Spear R E, Gardner G R. Dendrite cell size. AFS Transactions, 1963, 71: 209-215.

[14] Villeneuve C, MSamuel A, HSamuel F. Role of trace elements in enhancing the performance of 319 aluminum foundry alloy. Transaction of AFS and the proceedings of the One Hundred Fifth Annual Casting Congress, 2001, 109: 287-300.

[15] Wu Xiaobo, Zhang Henghua, Li Minmin, et al. Effects of Content and Morphology of Iron Phase on the Microstructure and Mechanical Properties of Eutectic Al-Si Alloy. Special Casting \& Nonferrous Alloys, 2007(1), 27: 64-67. (In Chinese)

This work was financially supported by the major project of Shandong Science and Technology (No. 2015ZDZX03004), the project of Shandong Science and Technology Development Plan (No. 2014GGX103035) and the National "Thousand Talents Plan" of China. 